\title{
Mineralization Process of Biocemented Sand and Impact of Bacteria and Calcium Ions Concentrations on Crystal Morphology
}

\author{
Guobin Xu, Yang Tang, Jijian Lian, Yue Yan, and Dengfeng Fu \\ State Key Laboratory of Hydraulic Engineering Simulation and Safety, Tianjin University, Tianjin 300072, China \\ Correspondence should be addressed to Yue Yan; yueyan_geo@126.com
}

Received 26 May 2017; Revised 18 August 2017; Accepted 29 August 2017; Published 12 October 2017

Academic Editor: Mikhael Bechelany

Copyright (c) 2017 Guobin Xu et al. This is an open access article distributed under the Creative Commons Attribution License, which permits unrestricted use, distribution, and reproduction in any medium, provided the original work is properly cited.

\begin{abstract}
Microbial-induced calcite precipitation (MICP) is a sustainable technique used to improve sandy soil. Analysis of the mineralization process, as well as different bacterial suspensions and calcium concentrations on the crystal morphology, revealed that the mineralization process included four stages: self-organised hydrolysis of microorganisms, molecular recognition and interface interaction, growth modulation, and epitaxial growth. By increasing bacterial suspensions and calcium concentrations, the crystal morphology changed from hexahedron to oblique polyhedron to ellipsoid; the best crystal structure occurs at $\mathrm{OD}_{600}=1.0$ and $\left[\mathrm{Ca}^{2+}\right]=0.75 \mathrm{~mol} / \mathrm{l}$. It should be noted that interfacial hydrogen bonding is the main force that binds the loose sand particles. These results will help in understanding the mechanism of MICP.
\end{abstract}

\section{Introduction}

Microbial-induced calcite precipitation (MICP) is a sustainable, biological technique that could alter and improve the mechanical and geotechnical engineering properties of soil. The formed precipitates could bind the soil particles (e.g., sand and gravel) together to form a composite material (Figure 1).

Nowadays, the MICP technology is used in many geotechnical engineering applications, such as wind erosion control of sandy soil [1], promoting the consolidation of fine tailings [2], stabilisation of sandy soil foreshore slop [3], and improving the compressibility and shear strength of organic soil [4]. It has also shown great potential in engineering applications [5].

To further improve the mechanical properties of the material after MICP treatment, many scholars have studied the relevant crystal mineralization process and analysed its influence on the soil mechanical properties. Dhami et al. [6] reported that the biochemical processes produced a mixture of two forms of carbonate (calcite and vaterite) in different proportions. Therefore, controlling these biochemical processes could enable one to engineer the mechanical properties of the carbonates. Cheng et al. [7] reported the effects of several key environmental parameters on ureolytic MICPmediated soils. Their results showed that an effective crystal precipitation pattern could be obtained at low urease activity and ambient temperature. The resulting large, agglomerated clusters fill the gaps between the soil grains, leading to effective crystal formation. The urease activity to induce carbonate precipitation in microorganisms has been discussed by several other researchers [8-10].

Feng and Montoya [11] found that, at a given effective confining pressure, the stiffness, peak shear strength, and dilation of the soil increase with the calcite content $[12,13]$. Moreover, the ratio of urea and calcium chloride consumed in the columns has a linear relationship with the percentage of deposited calcium carbonate [14].

All these results indicate that the calcium carbonate crystals can remarkably improve the mechanical properties of the soil. Abdel Gawwad et al. [15] believed that the compressive strength of prepared biomortar could be mainly attributed to the changing morphology of the mineral precipitated by bacteria cells within the sand grains. However, detailed research to characterise the changing crystal morphology is still lacking. The bacterial cells have little direct effect on the morphology of the crystals, which is mainly affected by the 
TABLE 1: Physical properties of the sand employed in this study.

\begin{tabular}{lcccr}
\hline Grain shape & $\begin{array}{c}\text { Specific } \\
\text { gravity } \\
\left(\mathrm{kg} / \mathrm{m}^{3}\right)\end{array}$ & $\begin{array}{c}\text { Medium } \\
\text { particle size } \\
(\mathrm{mm})\end{array}$ & Water content (\%) & $\begin{array}{c}\text { Tight porosity (\%) } \\
\text { composition }\end{array}$ \\
\hline Round & 2.65 & 0.21 & 0 & 40.5 \\
\hline
\end{tabular}

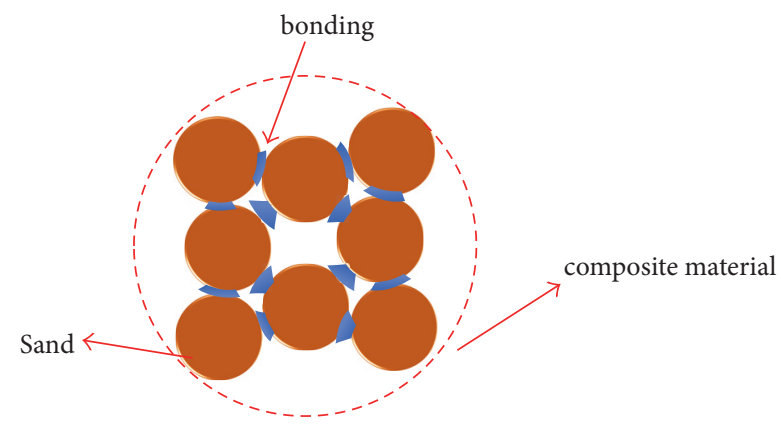

FIGURE 1: The bonding schematic of loose sand particles.

bacterial metabolic products distributed in the solution [16]. In other words, the crystal morphology is affected by these metabolic products, which in turn are related to the number of microorganisms and the cementation solution.

In the review by Anbu et al. [17], it was pointed out that microbial mineralization processes are usually slower and more complex than the chemical ones. Furthermore, the exact mechanism of precipitation and the function of this process in the ecology of the microorganism remain unresolved. So, the development of the biogeointerface and the associated mechanism should be explored [18].

To the best of our knowledge, there has been no report that systematically investigates the change in the crystal morphology of microbial-induced calcium carbonate precipitation. In this study, we examined the formation of crystals by microbial mineralization on a mesoscopic scale. The impact of two key parameters, namely, the concentrations of the bacteria $\left(\mathrm{OD}_{600}\right)$ and $\mathrm{Ca}^{2+}$ on the crystal morphology, was also analysed. The aim is to understand the mechanism of crystal formation during MICP at the microscale level (e.g., the self-organised hydrolysis of the microorganisms, crystal bonding, and crystal growth). The results will provide a new perspective on the preparation of composite materials with unique structure, properties, and different pore diameters.

\section{Materials and Methods}

2.1. Bacterial Suspension. An isolated bacterial culture of Sporosarcina pasteurii ATCC 11859 was used in this study. Sporosarcina pasteurii is a commonly used bacterium in the application of MICP technology, with several advantages stated by scholars, such as nonpathogenicity and high specific surface area of cell [19], high tolerance of both urea and calcium ion concentrations [20], and strong biological activity under harsh environment (like acid, alkali, high salinity, etc.) [21].

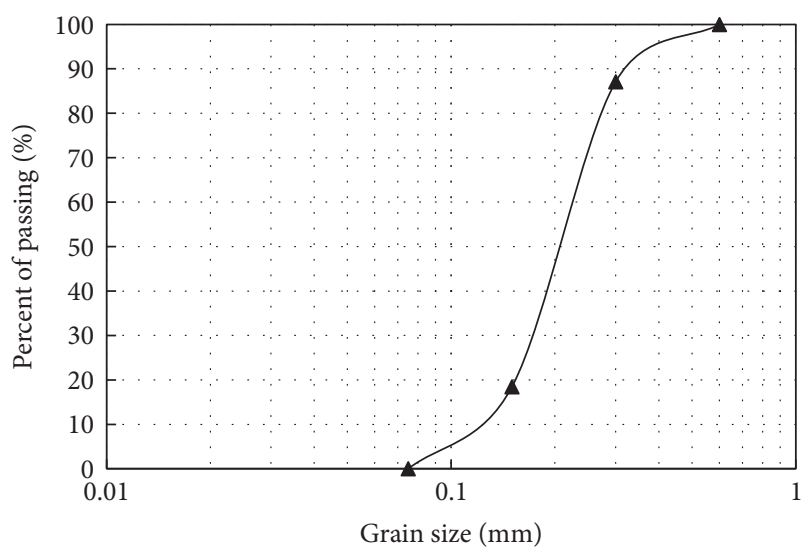

Figure 2: Grain size distribution of the sand.

The fermentation medium, which comprised yeast extract at $20 \mathrm{~g} / \mathrm{L}$, ammonium sulfate at $10 \mathrm{~g} / \mathrm{L}$, and Tris reagent at $17.5 \mathrm{~g} / \mathrm{L}$, was sterilized by autoclaving for $20 \mathrm{mins}$ at a temperature of $121^{\circ} \mathrm{C}$. After cooling, the medium was inoculated in a test tube and placed in a shaker for 24 hours at a temperature of $30^{\circ} \mathrm{C}$ and a rotational speed of $220 \mathrm{rpm}$ to preculture it until obvious turbidity appeared. This ensured the bacterial concentration $\mathrm{OD}_{600}$ reached the range of 2-3 and the urease activity was approximately $10 \mathrm{mmol}$ of hydrolysed urea/min. Then the bacterial suspension was placed into a refrigerator to be stored at a temperature of $4^{\circ} \mathrm{C}$. Before experimental use, the solution was shaken at $30^{\circ} \mathrm{C}$ inside the shaker to return to $10 \mathrm{mmol}$ of hydrolysed urea/min.

2.2. Cementation Solution. During mineralization, other types of calcium sources are converted into calcium carbonate [22], with $\mathrm{CaCl}_{2}$ being the most common source. On the other hand, according to the bacterial consolidation mechanism, urea and calcium sources are the basic ingredients of bacterial bonding. Therefore, a solution of $\mathrm{CaCl}_{2}$ and urea served as the fixation solution and cementation fluid in this study.

2.3. Properties of Sand. We used standard sand that had been passed through a $0.6 \mathrm{~mm}$ sieve. The basic characteristics are shown in Table 1. Its bulk density, dense packing density, loose porosity, and close packed porosity are 1.380 and $1.574 \mathrm{~g} / \mathrm{cm}^{3}$, and $47.9 \%$ and $40.5 \%$, respectively. Its grain size distribution is shown in Figure 2.

2.4. Instrumentation. A mould of polymethylmethacrylate tube (height: $15 \mathrm{~cm}$, inner diameter: $5 \mathrm{~cm}$ ) was used to create the specimens (Figure 3 ). The top of the tube was sealed with a rubber stopper, and its bottom was sealed by an organic glass 


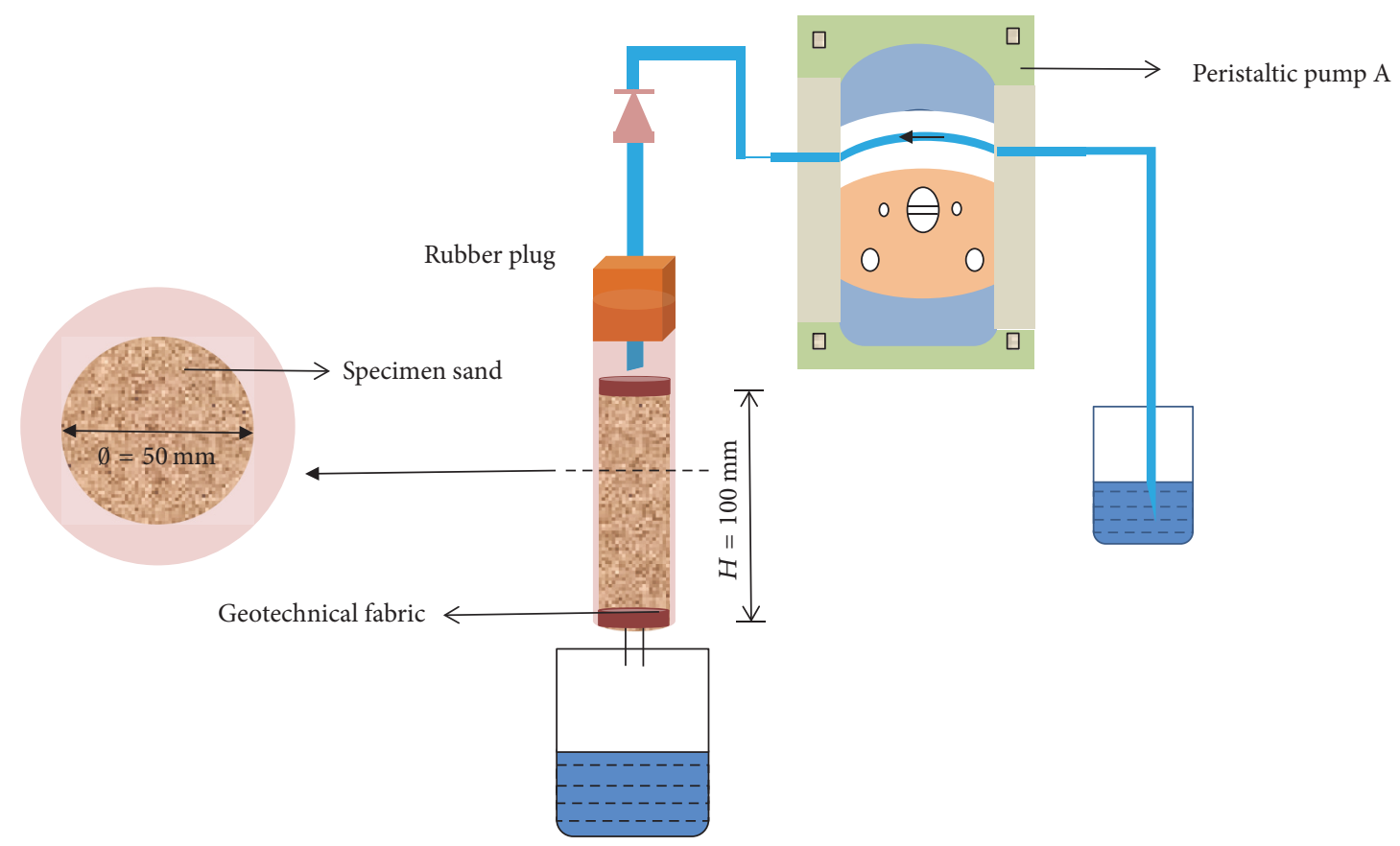

(a) Part A

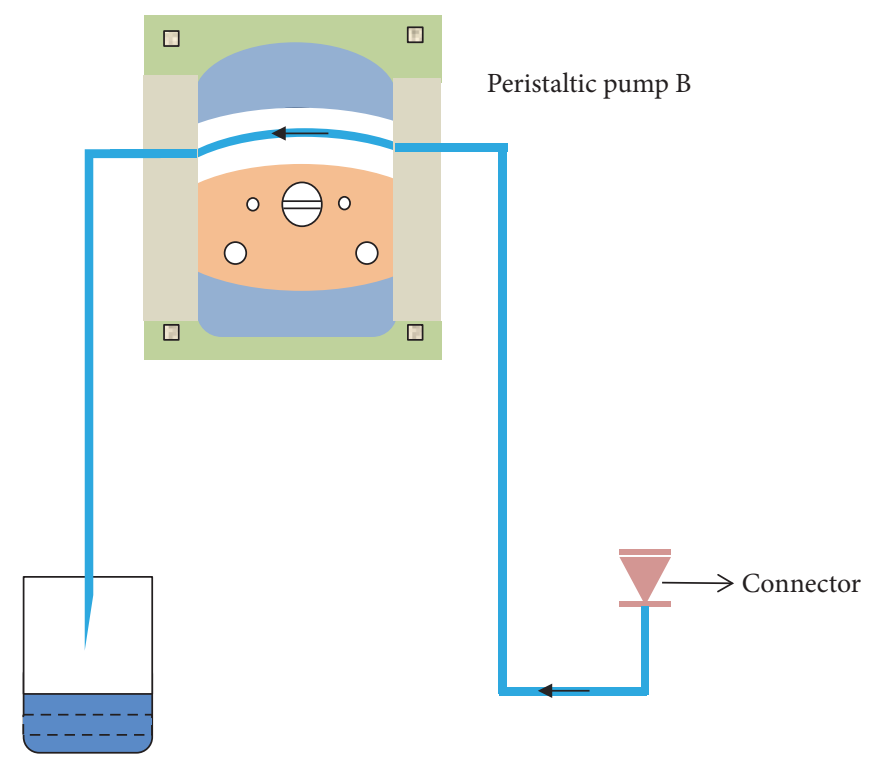

(b) Part B

FIGURE 3: Schematic of the mould.

plate with a central hole. After placing geotechnical fabric ( $0.5 \mathrm{~mm}$ thick) at the bottom of the tube, the test proceeds as follows:

(1) Both sands had greater than $98 \%$ silica $\left(\mathrm{SiO}_{2}\right)$. To keep the sand surface clean and deplete any soluble chemicals, the sands were initially soaked in $1 \mathrm{M}$ nitric acid solution for $24 \mathrm{~h}$ followed by cleaning with deionized water and drying in an oven at $105^{\circ} \mathrm{C}$ for $24 \mathrm{~h}$ prior to use. Subsequently, standard sand (Metage: $309 \mathrm{~g}$ ) was placed in the mould up to $10 \mathrm{~cm}$ in height and covered with geotechnical fabric $(0.5 \mathrm{~mm}$ thick) to create uniform liquid distribution. The pipe was then sealed with a rubber plug through which a hose of the peristaltic pump A was passed. The other end, that is, the bottom end of the tube, was open to the air (Figure 3(a)).

(2) Distilled water was pumped through the sand column in the pipe at a flow rate of $2 \mathrm{~mL} / \mathrm{min}$ for $24 \mathrm{~h}$ using the peristaltic pump (which was calibrated before testing). The purpose of this step was to prepare better flow channels for the next phase of injection. 
(3) Different bacterial and cementation solution concentrations were configured. In this paper, a visible light spectrophotometer (WFJ2000, UNICO) was used to detect the number of microorganisms. The wavelength was $600 \mathrm{~nm}$, and the measured value was $\mathrm{OD}_{600}$. If the bacteria $\mathrm{OD}_{600}$ value exceeded 0.8 , the bacteria solution needed to be diluted to a certain ratio so that the diluted bacteria $\mathrm{OD}_{600}$ value was between 0.2 and 0.8 , before measuring the $\mathrm{OD}_{600}$ value. The measured value multiplied by the corresponding dilution multiple was the actual $\mathrm{OD}_{600}$ value of the bacterial liquid. The $\mathrm{OD}_{600}$ values selected in this paper were $\mathrm{OD}_{600}=0.25,0.50,1.00,1.50$, and 2.00, respectively. In this experiment, a mixed solution of Urea-CaCl${ }_{2}$ was used where urea was the nitrogen and energy source of microbial growth, and $\mathrm{CaCl}_{2}$ was the calcium source in the process of MICP. The amount of urea and calcium ion maintained the same concentration in the mixed solution, which ensures the sufficient $\mathrm{CO}_{3}{ }^{2-}$ ions can be provided during the urease process for the decapitation of $\mathrm{Ca}^{2+}$ ions. A series of concentrations $(0.25,0.50,0.75$, 1.00 , and $1.50 \mathrm{~mol} / \mathrm{L}$ ) were adopted in the experiment. Subsequently, to verify the accuracy of the solution, the determination of calcium content in water EDTA titration method (ISO 6058-1984) was used to recheck the calcium concentrations. Correspondingly, the urea concentration was examined by PDAB method [23].

(4) The bacterial suspension was filled with the peristaltic pump and the injected flow rate and volume of the bacterial suspension were fixed at $5 \mathrm{~mL} / \mathrm{min}$ and $80 \mathrm{~mL}$, respectively. The hold time in loose sand was $5 \mathrm{~h}$.

(5) Afterwards, $80 \mathrm{~mL}$ of cementation solution containing urea and $\mathrm{Ca}^{2+}$ was injected into the sand column at the same flow rate $(5 \mathrm{~mL} / \mathrm{min})$, and the hold time was also $5 \mathrm{~h}$.

For the entire test procedure, each group of the same $\mathrm{OD}_{600}$ bacterial fluid was tested with $\mathrm{Ca}^{2+}$ concentration $\left(M_{\text {ca }}\right)=0.25,0.50,0.75,1.00$, and $1.50 \mathrm{~mol} / \mathrm{L}$, respectively. The flow rate, volume, and hold time in the experiment were performed according to Steps (4) and (5). The total number of experimental groups was 25, and, for each of the 25 test conditions, one addition of both bacteria and cementation solution for each condition tested. For a cycle, the injection number of cementation liquid is five times, and the injection number of bacterial liquid is one time. Two cycles were performed for each sample. During the test, whenever the liquid began to accumulate on the surface of the sand, the device in Part B was used to connect the bottom end of the tube using a connector (Figure 3(b)). The pumping rate of the peristaltic pump B was consistent with that of pump A. It should be noted that all experiments were performed at an ambient temperature of $25 \pm 3^{\circ} \mathrm{C}$.

2.5. Mineralogical and Textural Analysis System. As shown in Figure 4, the mineralogical and textural analysis system consist of fluorescence microscope, FTIR, XPS, SEM, and XRD. The fluorescence microscope (OLYMPUS CX41) at the State Key Laboratory of Systems Engineering, Tianjin University, was used to observe the morphological characteristics of the microorganism and mineralized crystal (if any), with the bacterial mineralization process being or not being involved. The dyeing of sample was achieved by dipping the basic fuchsin solution (mass fraction of $0.5 \%$ ) into the microbial bacteria preplaced on the slides, and the coverslip was placed over the sample for shaping a flat layer of even thickness. Note that the oil mirror was used for investigation during the microbial mineralization process where $0.05 \mathrm{ml}$ of cedar oil instead of the coverslip was used to seal the sample after dyeing process. Interactions among the microorganisms, mineralized crystals, and loose sand particles were analysed using the Fourier transform infrared spectrometer (FTIR, NEXUS 870, 32 scans at the resolution of $4 \mathrm{~cm}^{-1}$ ) and X-ray photoelectron spectroscope (XPS, PHI 5000 VersaProbe) at the testing centre at China National Academy of Nanotechnology and Engineering.

The cemented sand body on the surface of the column was examined using scanning electron microscopy (SEM) and $\mathrm{X}$-ray diffraction (XRD). The SEM observation conditions were as follows: $\mathrm{EHT}=5.00 \mathrm{kV}$ and $\mathrm{WD}=6 \mathrm{~mm}$. The XRD spectra were obtained using a $\mathrm{Cu}$ target $(40 \mathrm{kV}$ and $30 \mathrm{~mA})$. The scan was performed for $2 \theta=20^{\circ}-80^{\circ}$ at the scanning velocity of $0.15 \mathrm{~s} / \mathrm{step}$. The XRD analysis could identify different crystalline phases of calcium carbonate in the composition (calcite, aragonite, vaterite, etc.) by a comparison with standard diffraction patterns from the International Centre for Diffraction Data.

\section{Results}

3.1. Self-Organised Hydrolysis of Microorganisms. The morphological characteristic of the microorganism was first investigated. Basic fuchsine was added to the bacterial solution to facilitate observation of the microbes. Under the fluorescence microscope (Figure 5), it is obvious that the microbes clearly had slender shapes with rounded ends and were arranged singly or in chains. The single microbe is estimated to be $1.790 \mu \mathrm{m}$ long and $0.549 \mu \mathrm{m}$ in diameter.

During the process of growth, reproduction, and metabolism, microbial cells produce urease that promotes hydrolysis of urea, and $\mathrm{CO}_{3}{ }^{2-}$ ions necessary to the precipitation of $\mathrm{Ca}^{2+}$ ions in the following microbial mineralization process are constantly released from the cells.

\subsection{Microbial Mineralization Process, Molecular Recognition, and Interface Interaction}

3.2.1. Microbial Mineralization Process. The above-mentioned analysis shows that urea hydrolysis creates a selfadaptive microreaction (i.e., urea hydrolysis) environment through the enzymatic action prior to mineral precipitation. For brevity, in this subsection, we only present the experimental results under the conditions of $\left[\mathrm{Ca}^{2+}\right]=0.5 \mathrm{~mol} / \mathrm{L}$ and $\mathrm{OD}_{600}=1.5$. Figure 6 shows the microorganisms distributed 


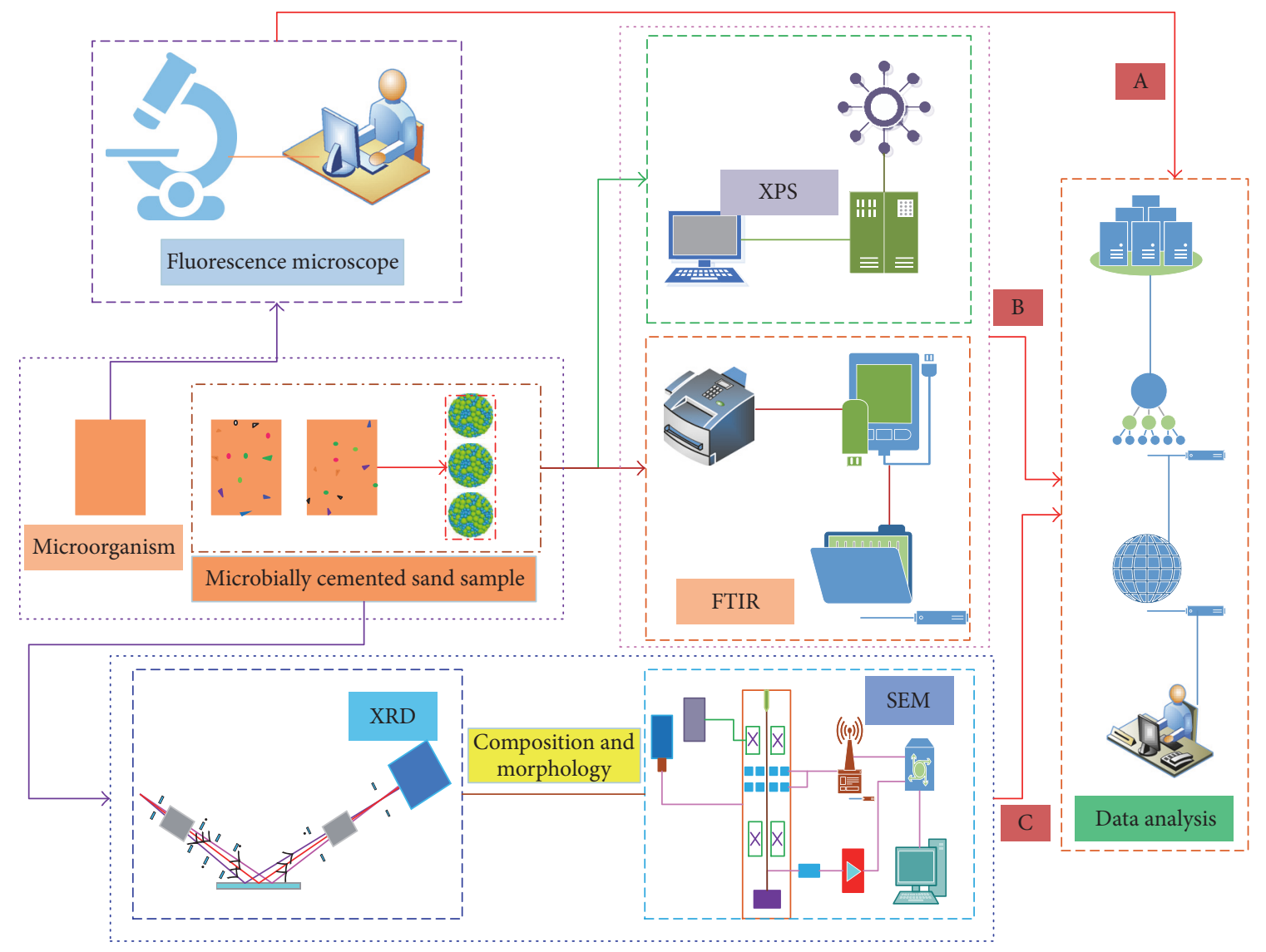

Figure 4: Mineralogical and textural analysis system.

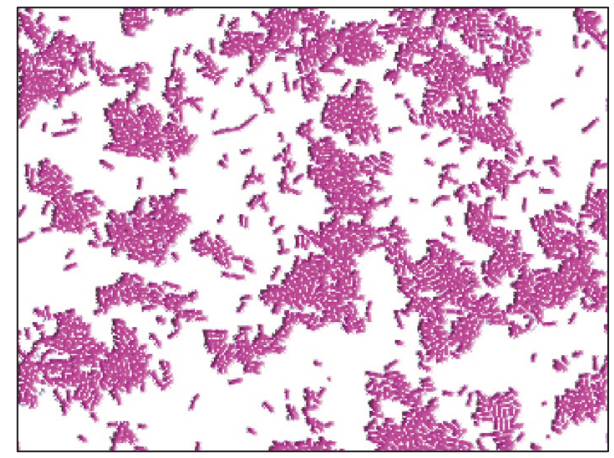

FIGURE 5: Morphological characteristics of microorganisms under fluorescence microscope.

among sand particles, which form the mineralization process of mineral nucleation kinetics. It is noted that, as time changes, at the beginning stage, the calcium ions have not been added (Figure 6(a)). Subsequently, a certain concentration of calcium ions was added. To better distinguish the bacterial substances from crystal, the microorganism rendered in pink using basic fuchsine, mixture of sand particles, and cementation solution, initial and stabilised crystals are defined by means of different characteristic values (RGB (243, 22, and 250); RGB (255, 255, and 255); RGB (10,
251, and 249); RGB (0, 20, and 250)), which corresponds to pink, white, light blue, and dark blue, respectively.

Before adding the $\mathrm{Ca}^{2+}$ ions and urea, Figure 6(a) clearly presents the slender microbes wrapped around a transparent material. After 1 min of observation, the slender rods changed into rings (Figure 6(b)) as the microorganisms on the sand particle surface begin to adapt to the environment, and the secreted substances from cell metabolism are wrapped on the microbial surface. It is noted that, at $0 \mathrm{~min}$, some microorganisms on the sand particle surface have already appeared in a ring shape. This may be because the mineralization processes have occurred among these zones in accordance with an artificially defined zero time. Subsequently, the $\mathrm{Ca}^{2+}$-urea solution was dropped on the slide with the same concentration, and the mineralization processes are shown in Figures 6(c) $-6(\mathrm{~h})$.

From Figure 6(c), it is evident that, after adding the $\mathrm{Ca}^{2+}$ ions, some ring-like substance was formed, together with the partial aggregation of small grains. Furthermore, the ringlike substance was dispersed in the solution and around the microbes. This can be explained by the fact that urea hydrolysis occurred preferentially at certain $\mathrm{Ca}^{2+}$ and urea concentrations. Subsequently, the floc was produced by electrostatic interaction between $\mathrm{Ca}^{2+}$ and $\mathrm{CO}_{3}{ }^{2-}$ in the solution. At this moment, the floc was attached to the microbial surface due to the charges on the latter [22]. 


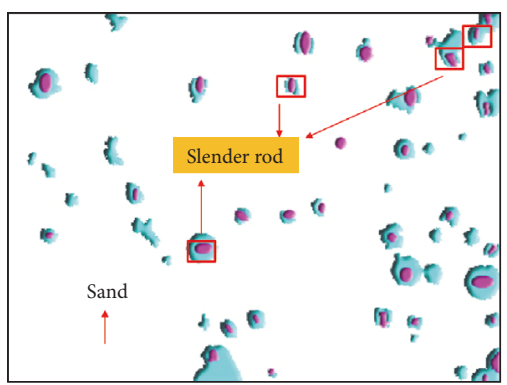

(a) $0 \mathrm{~min}$

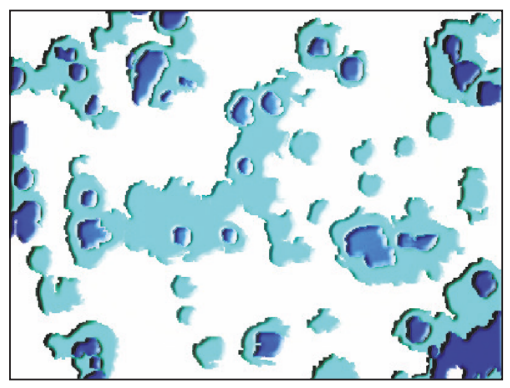

(d) $20 \mathrm{~min}$

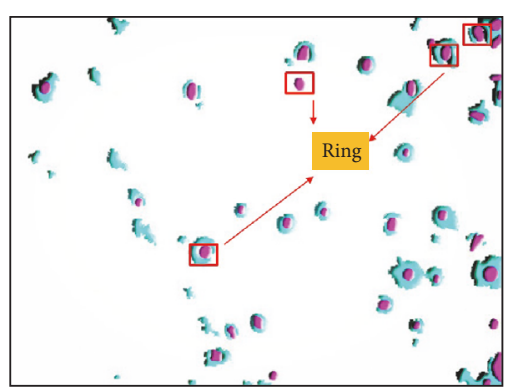

(b) $1 \mathrm{~min}$

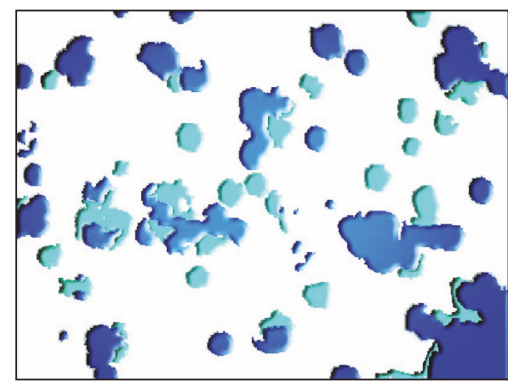

(e) $40 \mathrm{~min}$

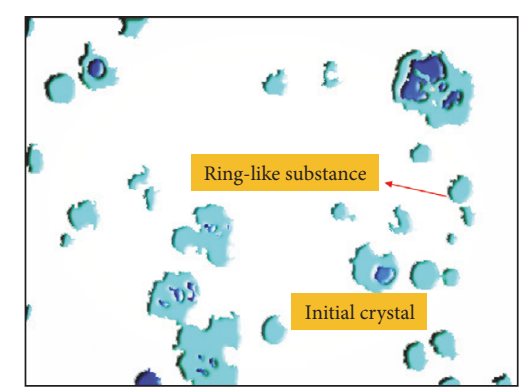

(c) $5 \mathrm{~min}$

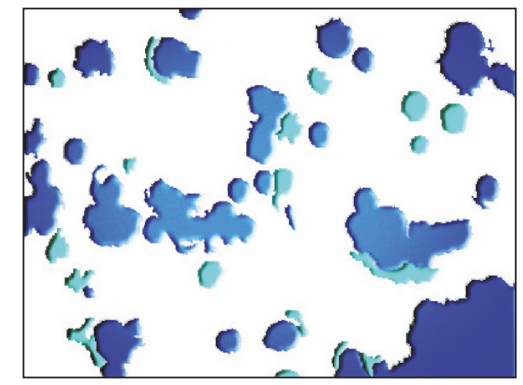

(f) $70 \mathrm{~min}$

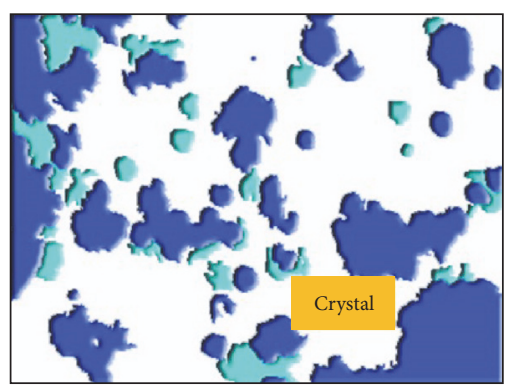

(g) $100 \mathrm{~min}$

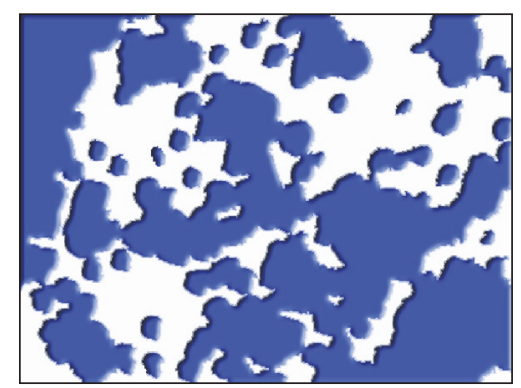

(h) $255 \mathrm{~min}$

FIGURE 6: The mineralization process by microbes under fluorescence microscope (1000x).

After $20 \mathrm{~min}$, the amount of substance around the sand particles obviously increased. A handful of mineralized crystals formed at the microbial periphery and became agglomerated. At this point, the bacteria had gradually adapted to the solution environment, urea hydrolysis occurred continuously, and the electrostatic interaction between $\mathrm{Ca}^{2+}$ and $\mathrm{CO}_{3}{ }^{2-}$ led to the growth of microbial mineralization products. It was noted that the whole process was centralized around the microorganisms.

When the reaction time was extended to $70 \mathrm{~min}$, the ringlike substance on the surface of sand particles continuously merged and grew into larger mineralized crystals. This phenomenon was particularly prominent at $100 \mathrm{~min}$ and indicated that the mineralization by microbial cells occurred extensively between the sand particles. Consequently, the intergranular pores were gradually filled, and the sand particles were wrapped within the minerals to form an amorphous, closely packed mass.

After $255 \mathrm{~min}$, the number of mineral crystals on the sand surface continued to increase, and the ring-like material completely disappeared, revealing a stable, solid mineral crystal. At the same time, the crystals came into contact with each other and adhered to the sand particle surface. This showed that there was considerable interaction between the sand particles and the mineralized crystals.

Next, the mineralization process was examined under the fluorescence microscope, with the same microbial and $\mathrm{Ca}^{2+}$ ion concentrations, but without the sand particles. At $0 \mathrm{~min}$, only the aggregated microbes were observed (Figure 7(a)), and the obvious slender shape was not monitored due to the smaller magnified ratio adopted in the testing. After $30 \mathrm{~min}$, a small amount of mineralized crystals was arbitrarily formed in the solution (Figure $7(b)$ ). As the reactions continued, after $90 \mathrm{~min}$, the products of mineralization continued to accumulate, forming a close packing configuration at $120 \mathrm{~min}$ (Figure 7(e)). The detailed drawing in Figure 7(f) shows that the mineralized crystals gradually wrapped on the surface of the living microorganism. In other words, the microorganisms provided nucleation sites for the mineralization process.

3.2.2. Interaction between Mineralized Crystals and Loose Sand Particles. As mentioned previously, the sand particles 


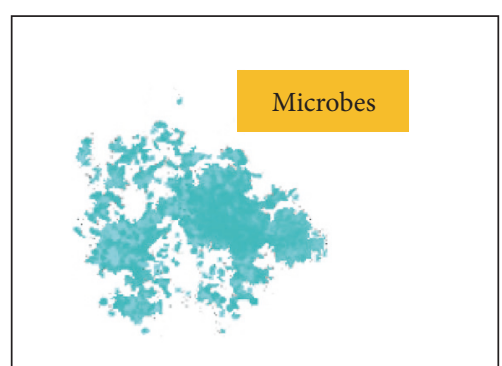

(a) $0 \mathrm{~min}$

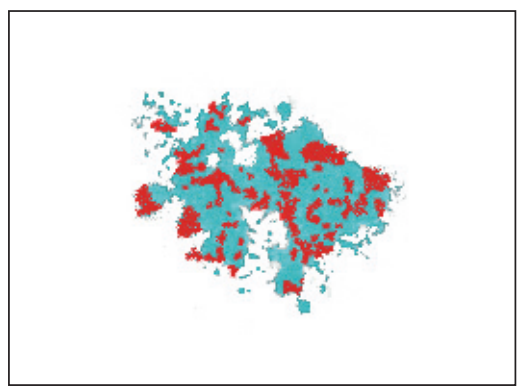

(d) $90 \mathrm{~min}$

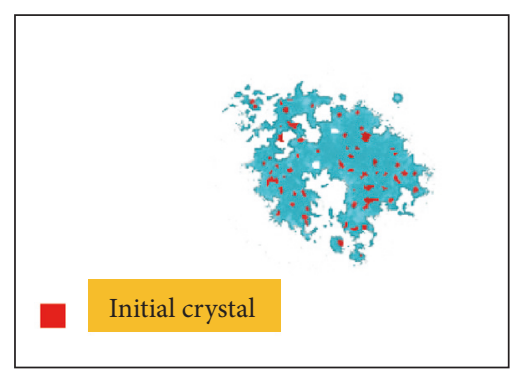

(b) $30 \mathrm{~min}$

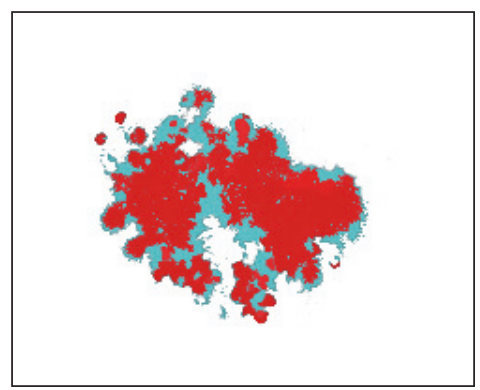

(e) $120 \mathrm{~min}$

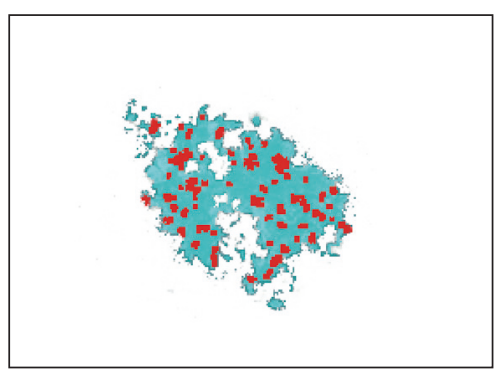

(c) $60 \mathrm{~min}$

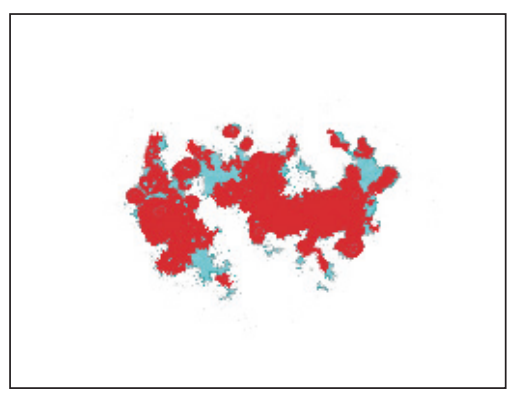

(f) $120 \mathrm{~min}$ (detail drawing)

FIGURE 7: Mineralization process with only microbes and cementing solution (1000x).

enhance the mobility of the microbes. When the sand particles are bound together by the mineralized crystals, the large sand-crystal interface further secures the crystals on the surface. Herein we compare the sand particles treated under three test conditions: (1) $\left[\mathrm{Ca}^{2+}\right]=0.5 \mathrm{~mol} / 1, \mathrm{OD}_{600}=1.5 ;(2)$ $\left[\mathrm{Ca}^{2+}\right]=1.0 \mathrm{~mol} / \mathrm{l}, \mathrm{OD}_{600}=0.5$; and (3) no $\mathrm{Ca}^{2+}$ or bacteria, by using IR and XPS analyses.

(1) Vibration Frequency. Figure 8 shows the IR spectra of pure sand particles and those after MICP treatment. It is evident that the latter exhibited bands corresponding to $\mathrm{C}-\mathrm{O}$ bond symmetric stretching vibration (1791.30 and $\left.1804.35 \mathrm{~cm}^{-1}\right)$. In addition, IR peaks corresponding to polypeptides were also observed at 869.57 and $867.60 \mathrm{~cm}^{-1}$. Therefore, the sand particles were bound by a mixture of mineral crystals and organic compounds, indicating that the microorganisms formed the nucleation sites. None of these IR peaks were observed in the pure sand sample. Furthermore, the IR peaks shifted slightly with the bacterial and $\mathrm{Ca}^{2+}$ concentrations: from 1791.30 to $1804.35 \mathrm{~cm}^{-1}\left(+13.05 \mathrm{~cm}^{-1}\right)$ for the C-O stretch and from 869.57 to $867.60 \mathrm{~cm}^{-1}\left(-1.97 \mathrm{~cm}^{-1}\right)$ for the polypeptides, respectively.

The Si-O bond symmetric stretching frequencies of the two sand samples after MICP treatment were 773.91 and $778.50 \mathrm{~cm}^{-1}$. Compared to pure sand $\left(777.91 \mathrm{~cm}^{-1}\right)$, these frequencies were shifted by +4 and $-0.59 \mathrm{~cm}^{-1}$, respectively. This indicates that the environment on the sand surface is changed by microbial-induced calcium carbonate precipitation. Specifically, the $\mathrm{O}$ atom in the $\mathrm{Si}-\mathrm{O}$ bond interacts with the hydroxyl group $(-\mathrm{OH})$ in the polypeptides, leading to strong intermolecular hydrogen bonding $(\mathrm{O}-\mathrm{H}---\mathrm{O})$. This bonding changed the electron cloud distribution along the SiO bond (Figure 9).

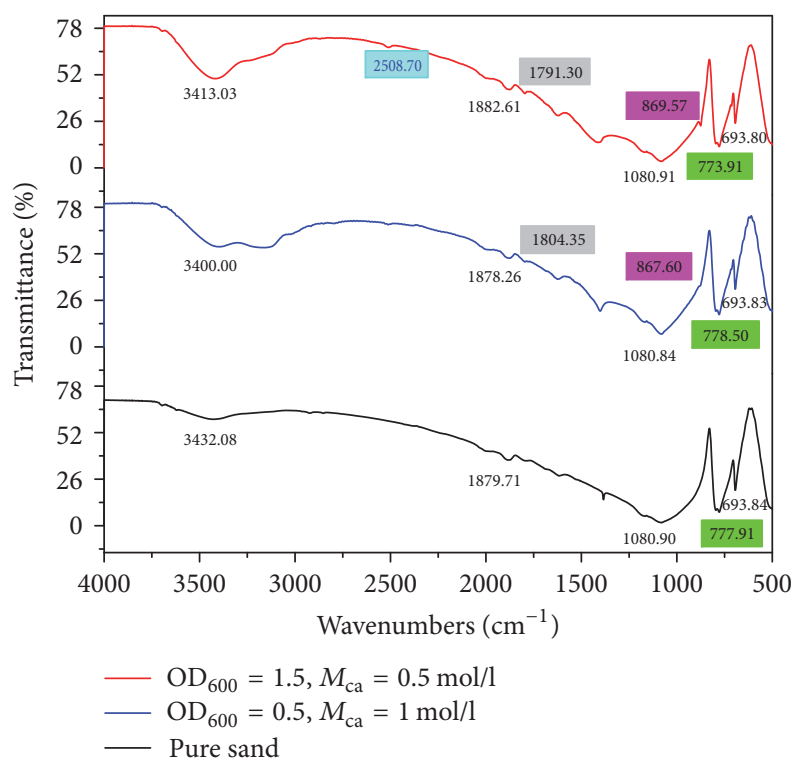

Figure 8: FTIR of sand particles after MICP treatment.

(2) XPS Analysis of Si. Figure 10 shows the Si (2p) XPS peaks (binding energy of the photoelectrons versus the relative signal strength $(\mathrm{c} / \mathrm{s}))$. The vertical ordinate represents the relative signal strength $(\mathrm{c} / \mathrm{s})$, and the horizontal ordinate represents the bonding energy. It is evident that there are two different $\mathrm{Si}$ environments. The $\mathrm{Si}(2 \mathrm{p})$ binding energy in pure sand is $102.95 \mathrm{eV}$, which was reduced to 102.71 and $102.66 \mathrm{eV}$ after MICP treatment (by $0.24-0.29 \mathrm{eV}$ ). This is due to the fact that there exist fewer $\mathrm{O}$ atoms around the $\mathrm{Si}$ atom. The electron cloud distribution of $\mathrm{Si}$ atom valence is larger than 


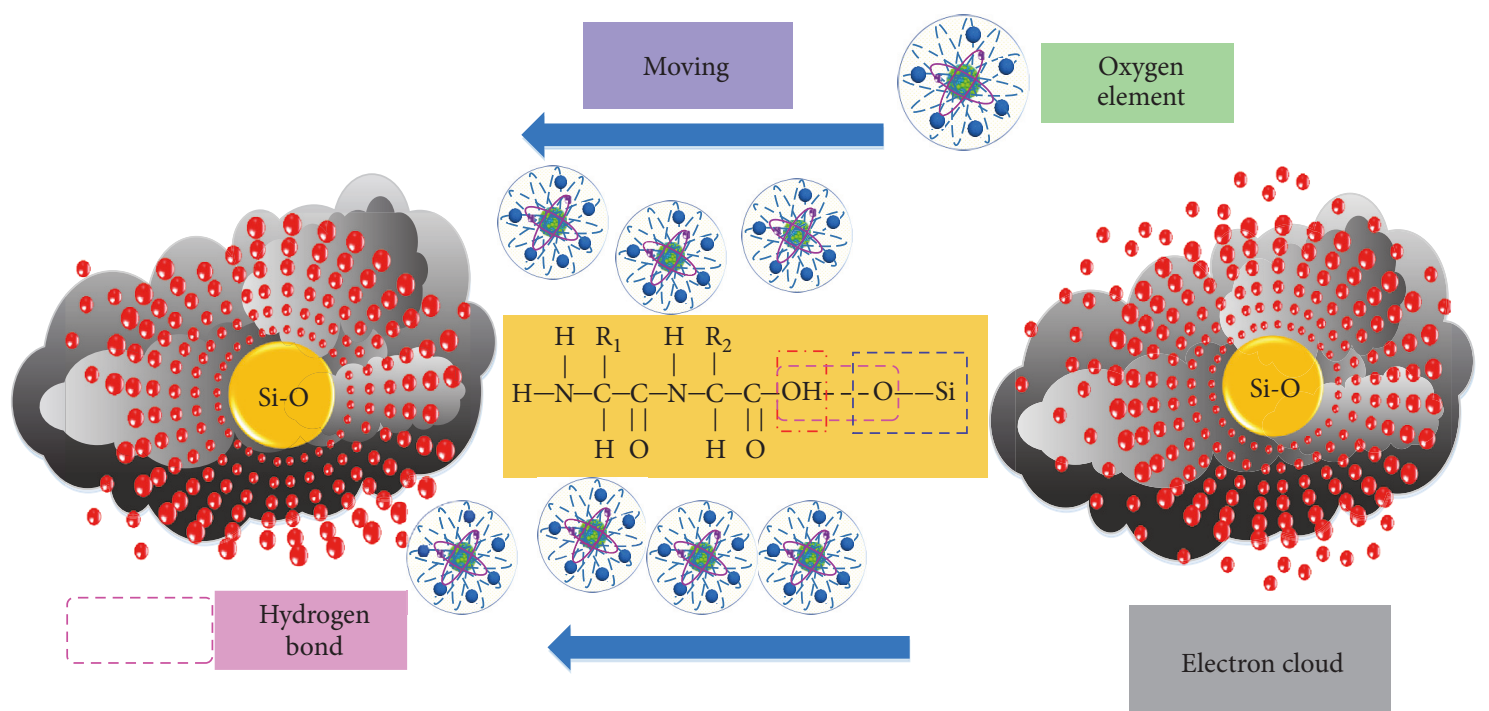

FIGURE 9: The process of hydrogen bonding formation between Si-O and hydroxyl groups in the polypeptides.

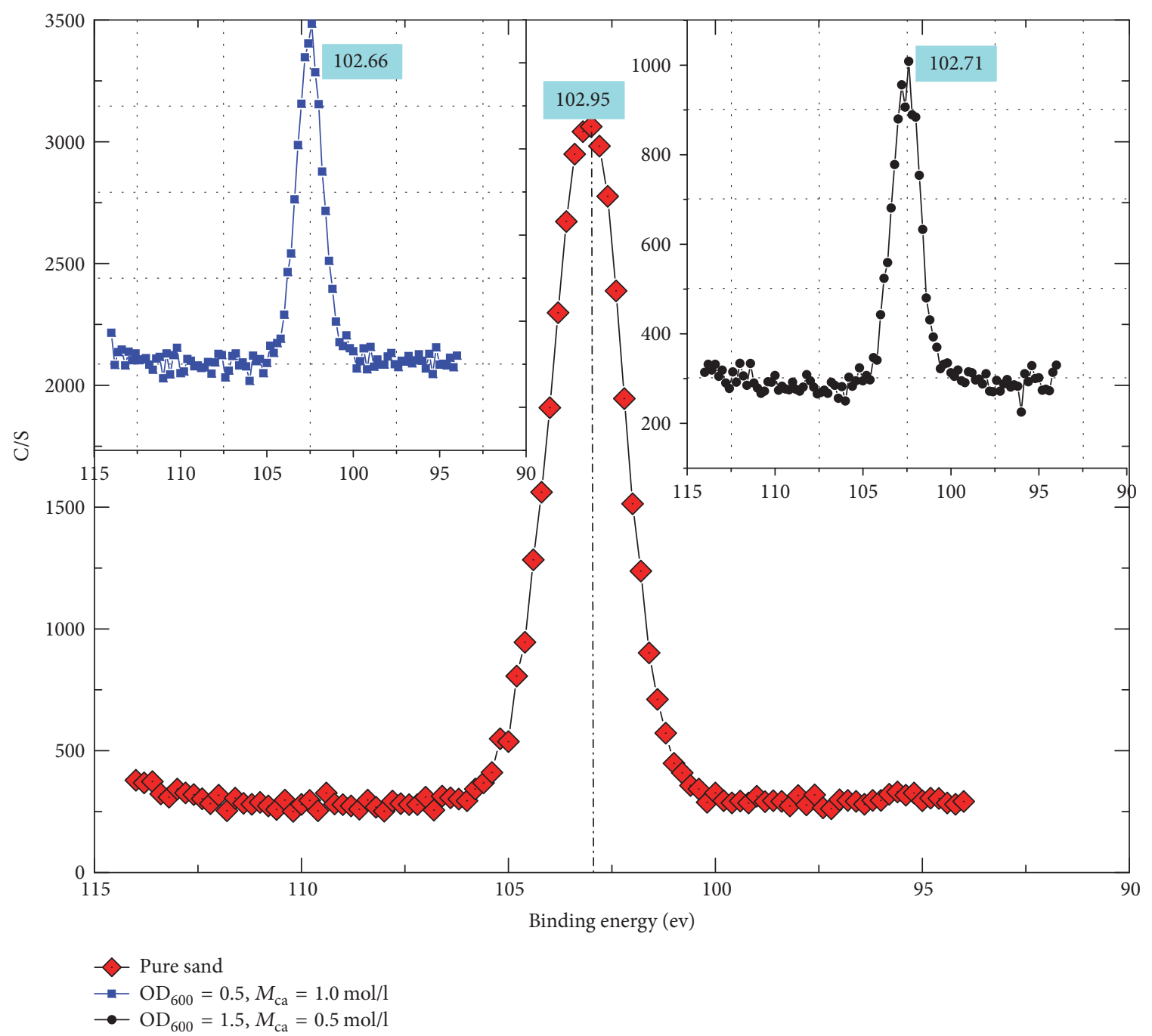

FIGURE 10: XPS peaks of Si (2p) for sand under different environments. 
that of $\mathrm{O}$ atom, and its electric shielding effect is stronger, and the result easily causes the 2 p electron separated from the atomic nucleus of Si atom, which leads to the reduction of the binding energy. This result, in agreement with the IR spectra, further confirms that the environment of the sand particles can be changed by the MICP treatment.

In summary, the effect of MICP treatment on the sand particle was examined at the microscopic level. Interactions are formed at the interface between the crystals and the sand particles. This interaction affects the chemical environment of $\mathrm{Si}$ atoms in the sand particles significantly. Interfacial hydrogen bonding is the essential cause of the binding of loose sand particles.

3.3. Growth Modulation and Epitaxial Growth. The morphologies of the crystals formed under different test conditions are shown in Figure 11. We use A, B, C, D, and E to label the $\mathrm{OD}_{600}$ values of $0.25,0.5,1.0,1.5$, and 2.0 , respectively, while $1,2,3,4$, and 5 represent the $\mathrm{Ca}^{2+}$ ion concentrations of $0.25,0.5,0.75,1.0$, and $1.5 \mathrm{~mol} / \mathrm{l}$. According to the XRD results, the cemented sand was mainly composed of quartz and calcite phases, as shown in Figure 12.

As we discussed earlier, in the microbial mineralization process, firstly urea is hydrolysed by the microorganisms, and the hydrolysis products initiated the formation of $\mathrm{CaCO}_{3}$ from $\mathrm{Ca}^{2+}$ and $\mathrm{CO}_{3}{ }^{2-}$. The sand particles are bound together mainly due to hydrogen bonding. Compared with the pure sand particles (Figure $11(\mathrm{~F}-0)$ ), it is clear that the formed calcite crystals on the sand surface have a variety of morphologies. Furthermore, the hollow parts of sand particles are filled with mineralized crystals (Figures 11(A-5), 11(C-5), and $11(\mathrm{E}-1)$ ), confirming the existence of the interaction between the crystal and sand particle at their interface.

According to Figures 8 and 10, the MICP treatment changed the surface bond vibration frequency and photoelectron binding energy of sand. The corresponding morphologies are shown in Figures 11(B-4) and 11(D-2). Clearly, the morphological feedback at the microscopic level is different. According to the SEM observations in Figure 11, the bacterial and $\mathrm{Ca}^{2+}$ ion concentrations indeed affected the crystal morphology, that is, the growth modulation and epitaxial growth.

3.3.1. Influence of $\mathrm{Ca}^{2+}$ Ion Concentration. For $\mathrm{OD}_{600}=0.25$ and 0.5 , the calcite crystals evolved with the same trend as the $\mathrm{Ca}^{2+}$ ion concentration was increased: gradually from hexahedron to ellipsoid, oblique polyhedron, and irregular shapes. The single crystal particles became larger, with the final crystals formed by interpenetrating multiple crystal particles, displaying a crystal growth process. When $\left[\mathrm{Ca}^{2+}\right]$ $=0.5 \mathrm{~mol} / \mathrm{l}$, a large amount of homogeneous, hexahedral $\mathrm{CaCO}_{3}$ crystal particles about $10 \mu \mathrm{m}$ in diameter were accumulated by regular plate-like structures with smooth surface (Figures 11(A-2) and 11(B-2)). The surface of some $\mathrm{CaCO}_{3}$ crystals was composed of small "flying disk"-shaped particles, and their morphology was analogous to the $\mathrm{CaCO}_{3}$ crystals synthesised by Yang et al. [24].

When $\mathrm{OD}_{600}=1.0$, the amount of formed calcite crystals increased gradually as $\left[\mathrm{Ca}^{2+}\right]$ ion concentrations gradually changed from 0.25 to $1.5 \mathrm{~mol} / \mathrm{L}$. This is especially clear in Figure $11(\mathrm{C}-3)\left(\mathrm{OD}_{600}=1.0,\left[\mathrm{Ca}^{2+}\right]=0.75 \mathrm{~mol} / \mathrm{L}\right)$, when $\left[\mathrm{Ca}^{2+}\right]$ was further increased to $0.75 \mathrm{~mol} / 1$. In this case, we observed relatively separated crystals consisting of multiple interpenetrating particles twin (Figures 11(C-1), 11(C-3), and $11(\mathrm{C}-4)$ ), in spite of the overlap between single crystals. The overall crystal shapes are oblique hexahedra and ellipsoids. It shows that the crystal growth process is modulated; otherwise it is difficult to form an independent system between single crystals and each other.

When $\mathrm{OD}_{600}=1.5$ or 2.0 and $\left[\mathrm{Ca}^{2+}\right]=0.25 \mathrm{~mol} / \mathrm{L}$, the single crystal particle shows a certain loose accumulation under the growth modulation (Figures 11(D-1), 11(E-1), and $11(\mathrm{E}-2))$. The large crystals in this case are mainly hexahedral. When the $\left[\mathrm{Ca}^{2+}\right]$ ion concentrations gradually changed from 0.75 to $1.5 \mathrm{~mol} / \mathrm{L}$, the crystals gradually became ellipsoidal. Moreover, the number of crystals adsorbed on the sand particle surface obviously decreased (Figures 11(D-4), 11(E-4), and $11(\mathrm{E}-5))$.

In summary, we found obvious differences in the morphology of calcite crystals formed under different $\left[\mathrm{Ca}^{2+}\right]$ conditions, based on the SEM micrographs (Figure 11). The final calcite crystal morphologies were oblique polyhedron, ellipsoid, and irregular. The volume of the crystal also continuously changed as $\left[\mathrm{Ca}^{2+}\right]$ was increased. These results indicate that the $\mathrm{Ca}^{2+}$ ions are the main factor in crystal formation, and the growth of crystals occurs on the surface of microorganisms. Therefore, $\left[\mathrm{Ca}^{2+}\right]$ indeed has a significant effect on the crystal growth.

3.3.2. Influence of $O D_{600}$. As a complex biological system, bacteria metabolism may provide the favourable microenvironments such as carbonate supersaturation for crystallization [25]. When $\left[\mathrm{Ca}^{2+}\right]=0.25 \mathrm{~mol} / 1$ and $\mathrm{OD}_{600}=0.25$, the formed crystals have a rough surface and internal defects, and the single crystal phenomenon is more obvious (Figures $11(\mathrm{~A}-1)$ and $11(\mathrm{~B}-1))$. When $\mathrm{OD}_{600}$ values gradually changed from 0.5 to 2.0 , the phenomenon of single crystal still exists (Figure 11(E-1)). But the crystal surface becomes smooth, and the crystal growth is improved. In this case, although $\left[\mathrm{Ca}^{2+}\right]$ is lower, the concentration of microorganisms is sufficiently enough that the charges on their surface further separated the nucleation sites, thereby facilitating epitaxial crystal growth.

When $\left[\mathrm{Ca}^{2+}\right]=0.5 \mathrm{~mol} / \mathrm{l}$ and $\mathrm{OD}_{600}$ values gradually changed from 0.25 to 2.0, the diameter of the calcite crystal particles is also increased [26]. The bonding among the regular hexahedral-shaped crystal particles changes, namely, from the simple bonding in Figure $11(\mathrm{~A}-2)\left(\mathrm{OD}_{600}=0.25,\left[\mathrm{Ca}^{2+}\right]=\right.$ $0.50 \mathrm{~mol} / \mathrm{L}$ ) to the winding and embedding (Figures 11(B-2), $11(\mathrm{C}-2)$, and $11(\mathrm{D}-2))$. As $\left[\mathrm{Ca}^{2+}\right]$ in the surrounding solution is increased from 0.25 to $0.5 \mathrm{~mol} / \mathrm{l}$, the microorganisms in it can obtain more needed energy for metabolism, at the same time the self-organised hydrolysis of microorganisms produces more $\mathrm{CO}_{3}{ }^{2-}$ ions. Moreover, the formed crystal particles constantly accumulate, and the environments under different $\mathrm{OD}_{600}$ are different. Finally, the crystal particle surfaces have different structures, leading to different final crystal shapes. It is evident from Figure 11 that as $\left[\mathrm{Ca}^{2+}\right]$ ion concentrations 


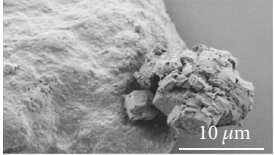

(A-1)

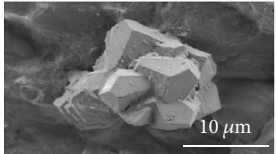

(A-4)

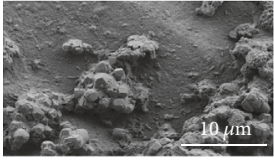

(B-2)

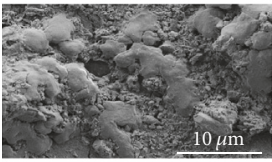

(B-5)

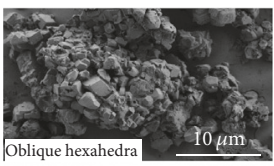

(C-3)

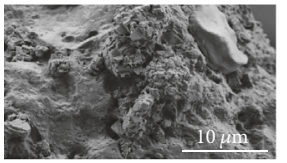

(D-1)

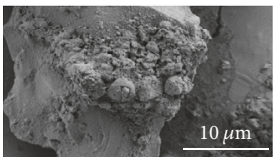

(D-4)

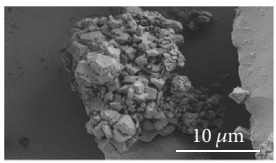

(E-2)

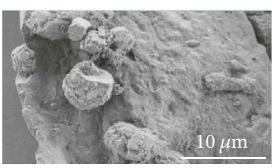

(E-5)

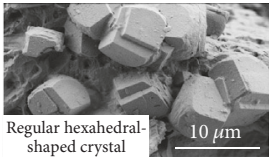

(A-2)

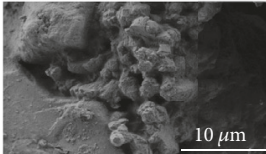

(A-5)

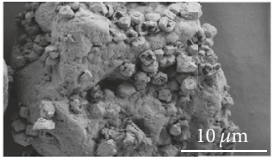

(B-3)

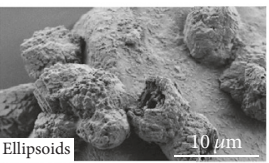

(C-1)

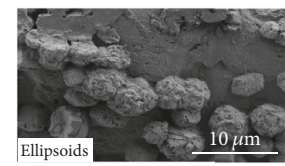

$(\mathrm{C}-4)$

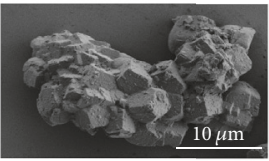

(D-2)

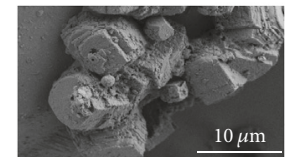

(D-5)

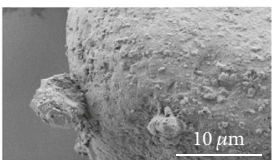

(E-3)

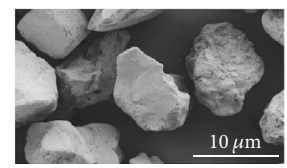

(F-0)

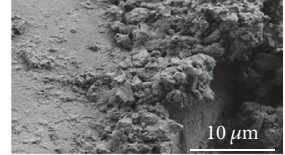

(A-3)

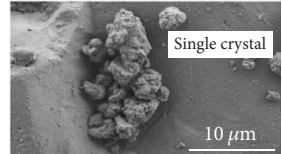

(B-1)

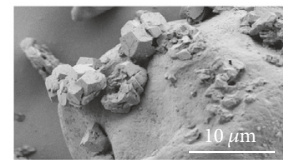

(B-4)

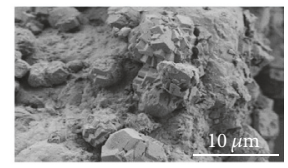

$(\mathrm{C}-2)$

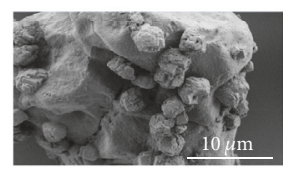

$(\mathrm{C}-5)$

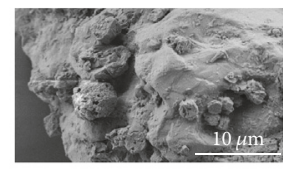

(D-3)

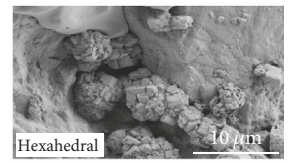

(E-1)

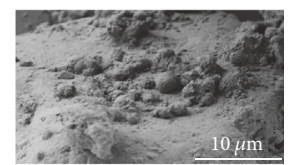

(E-4)

FIGURE 11: SEM micrographs of $\mathrm{CaCO}_{3}$ crystals under different bacterial suspensions and calcium concentrations $((\mathrm{A}-1)-(\mathrm{A}-5), \mathrm{OD} 600=0.25$ and $\mathrm{Ca}^{2+}$ concentration $\left(M_{\mathrm{ca}}\right)=0.25,0.50,0.75,1.00$, and $1.50 \mathrm{~mol} / \mathrm{L}$, resp.; (B-1)-(B-5), $\mathrm{OD}_{600}=0.50$ and $\mathrm{Ca}^{2+}$ concentration $\left(M_{\mathrm{ca}}\right)=0.25$, $0.50,0.75,1.00$, and $1.50 \mathrm{~mol} / \mathrm{L}$, resp.; $(\mathrm{C}-1)-(\mathrm{C}-5), \mathrm{OD}_{600}=1.00$ and $\mathrm{Ca}^{2+}$ concentration $\left(M_{\mathrm{ca}}\right)=0.25,0.50,0.75,1.00$, and $1.50 \mathrm{~mol} / \mathrm{L}, \mathrm{resp}$; $(\mathrm{D}-1)-(\mathrm{D}-5), \mathrm{OD}_{600}=1.50$ and $\mathrm{Ca}^{2+}$ concentration $\left(M_{\mathrm{ca}}\right)=0.25,0.50,0.75,1.00$, and $1.50 \mathrm{~mol} / \mathrm{L}$, resp.; $(\mathrm{E}-1)-\left(\mathrm{E}_{-} 5\right), \mathrm{OD}_{600}=2.00$ and Ca ${ }^{2+}$ concentration $\left(M_{\mathrm{ca}}\right)=0.25,0.50,0.75,1.00$, and $1.50 \mathrm{~mol} / \mathrm{L}$, resp.). 

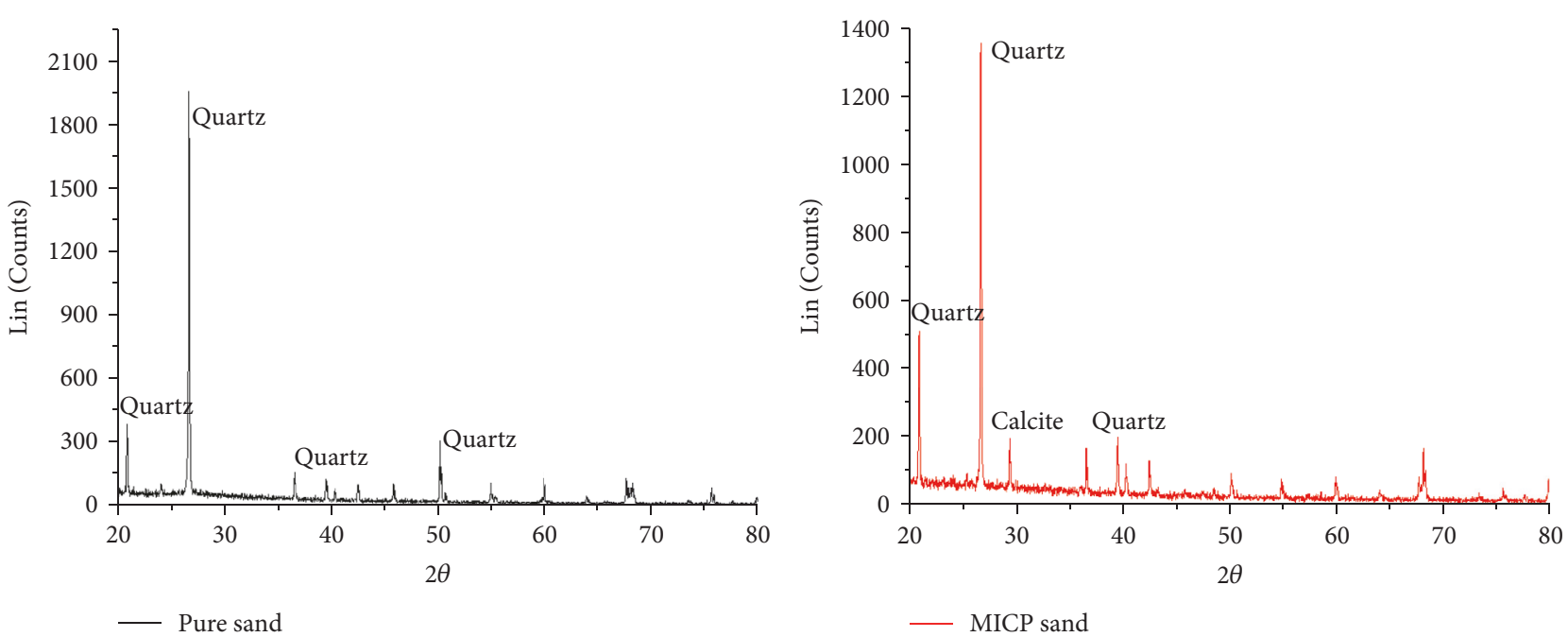

FIGURE 12: XRD patterns of the pure sand and the cemented sand under the $\mathrm{OD}_{600}=1.0,\left[\mathrm{Ca}^{2+}\right]=0.75 \mathrm{~mol} / \mathrm{l}$.

gradually changed from 0.25 to $1.5 \mathrm{~mol} / \mathrm{L}$ and $\mathrm{OD}_{600}$ values gradually changed from 0.25 to 2.0 , the crystal particles still showed different surface structures.

In summary, $\left[\mathrm{Ca}^{2+}\right]$ strongly affects the crystal size and growth, while the surface structure is related to the bacteria concentration. Together, these two factors modulate the crystal growth and create epitaxial growth. The surface and internal pore structure of the crystal (Figures 11(B-3), 11(C-1), 11(D-3), and 11(D-4)) may be caused by the following three factors:

(1) Hollows are created during the accumulation of different crystal particles.

(2) The self-organised hydrolysis of microorganism produces gas. During the mineralization and crystallization processes, the produced gas can form exhaust channels inside the crystal. The different growth environments modulate the crystal growth to form the unique structures.

(3) The final environment may contain substances that erode the crystal particles.

Despite the results obtained in this study, further exploration of the calcite crystal growth during MICP is needed. Note that internal defects can coexist with a smooth crystal surface (Figure 11(D-4)).

\section{Evaluation Analysis of Stacking Structures during the MICP Process}

During the MICP process, crystal growth occurs through their constant accumulation, and the crystal morphology keeps changing. If the bacteria are considered the primary structure, then the generated cluster structures on their surface are the secondary structure, which may further generate the ternary structure. The collision probability among crystals is obviously higher when the organic compounds are more concentrated (Figures 11(C)-11(E)). Thus, it is easy to generate the ternary-level structure (Figure 13). As a result, the interaction between organic and inorganic compounds and the charge density on the bacterial surface are the two key factors that affect the crystal morphology [25].

Lochhead et al. [27] analysed the interaction between organic and inorganic compounds and found that $\left[\mathrm{Ca}^{2+}\right]$ is higher at the cell membrane interface than in the surrounding solution, regardless of the base $\left[\mathrm{Ca}^{2+}\right]$ value in the solution. The polar groups of the surface organic compounds electrostatically attract and chelate $\mathrm{Ca}^{2+}$ ions near the cell surface, to eventually form $\left(\mathrm{Org}-\mathrm{Ca}^{2+}\right)_{i}{ }^{j}$ (Figure 13), which we call the basic cell. The existence of basic cell can effectively reduce the interface energy of crystal nucleation, which facilitates the nucleation and crystallization processes. The $\mathrm{Ca}^{2+}$ ions from the inorganic carbon source neutralise the negative charge on the bacterial surface, and the primary structure of the isotropic macromolecules with macroscopic area is gradually formed. Based on the model of [28] anion coordination polyhedron is usually the basic element of crystal growth, which constantly precipitates on the surface of the basic cell (through transfer, thermal convection, and other dynamic factors) to form a relatively independent growth site. When each site grows to a certain size, various accumulation structures cause steric hindrance changed by periodic charge layer. Then, the space limits the crystal growth in both kinetic and thermodynamic aspects, leading to incompletely developed crystals. In contrast, the small space between adjacent basic cells provides channels that are conducive to the crystal growth and space extension. Meanwhile, the various environments modulate the growth of the crystals to form hexahedral and oblique polyhedral and ellipsoidal shapes.

\section{Conclusions}

Based on our results, the mineralization process induced by microorganisms during MICP can be divided into four stages: 

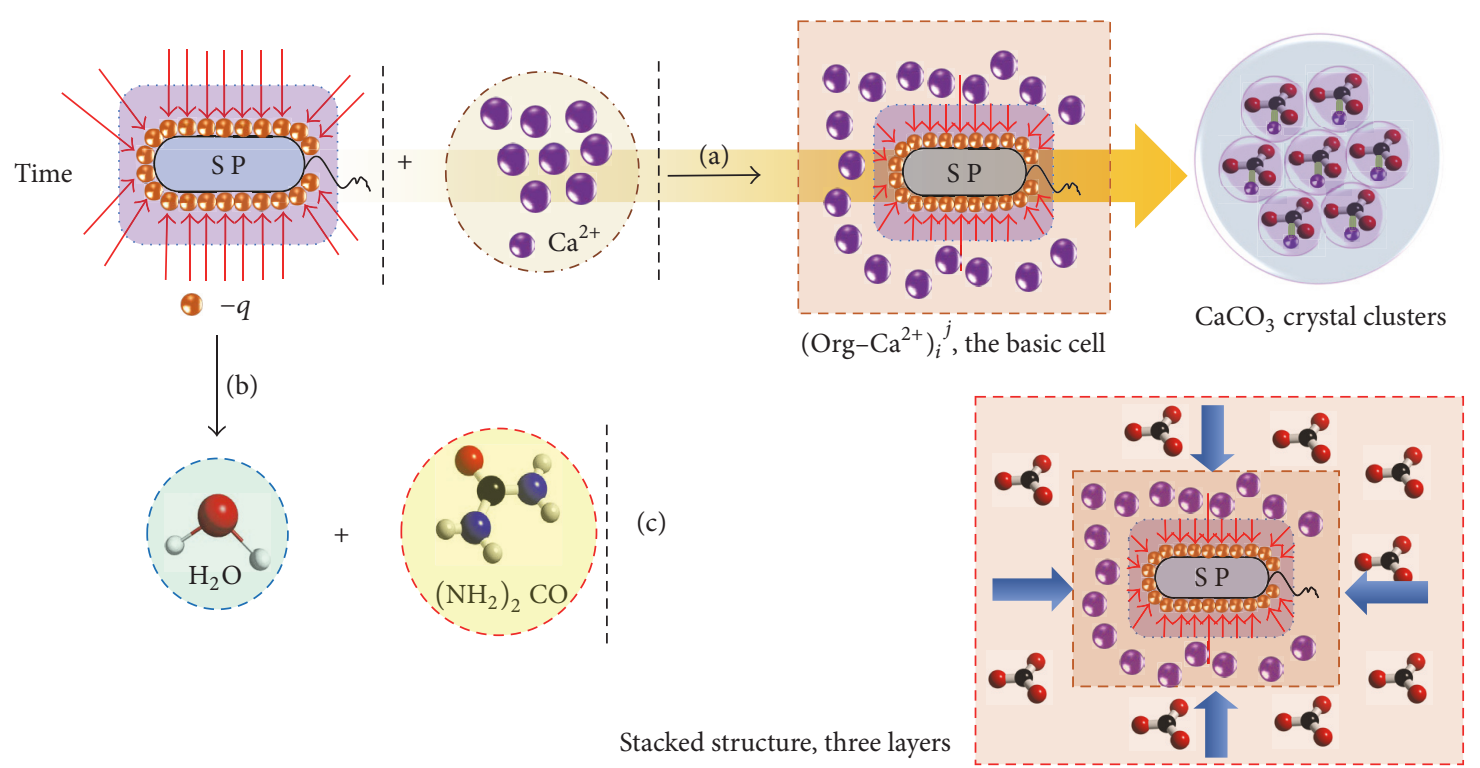

FIGURE 13: The generation of stacking structures.

self-organised hydrolysis of microorganism, precipitation reaction and interaction at the interface, growth modulation, and epitaxial growth. Interfacial hydrogen bonding is the essential cause of binding loose sand particles. The mineral precipitation is preceded by a self-adaptive microreaction environment caused by enzymatic action. The hydrolysis was shown to occur at specific $\mathrm{Ca}^{2+}$ and urea concentrations. When the $\mathrm{Ca}^{2+}$ ion concentration and bacterial fluid $\mathrm{OD}_{600}$ are changed, the morphology and number of mineralized crystals are changed significantly. The microorganisms themselves provided nucleation sites for the crystallization process with the crystals mainly being hexahedra and oblique polyhedra and ellipsoids, indicating modulated growth. The $\mathrm{Ca}^{2+}$ ion concentration mainly affects the crystal growth and their volume, and the bacteria $\mathrm{OD}_{600}$ adjust the surface structure. The best crystal structure occurs at $\mathrm{OD}_{600}=1.0$ and $\left[\mathrm{Ca}^{2+}\right]=$ $0.75 \mathrm{~mol} / \mathrm{l}$. However, the issue of internal structural defects needs to be further explored.

\section{Abbreviations}

MICP: Microbial-induced calcite precipitation

FTIR: Fourier transform infrared

XPS: X-ray photoelectron spectroscopy

SEM: Scanning electron microscopy

XRD: X-ray diffraction.

\section{Conflicts of Interest}

The authors declare that there are no conflicts of interest regarding the publication of this paper.

\section{Acknowledgments}

The authors would like to acknowledge the support received from the National Key R\&D Program of China
(2016YFC0401904), Science Fund for Creative Research Groups of the National Natural Science Foundation of China (51621092), National Natural Science Foundation of China (51579172, 51409187), and the Program of Introducing Talents of Discipline to Universities (B14012). In addition, the authors would like to acknowledge Dr. Zhu Jiaqing, for his assistance in the test.

\section{References}

[1] M. Maleki, S. Ebrahimi, F. Asadzadeh, and M. Emami Tabrizi, "Performance of microbial-induced carbonate precipitation on wind erosion control of sandy soil," International Journal of Environmental Science and Technology, vol. 13, no. 3, pp. 937944, 2016.

[2] J. Liang, Z. Guo, L. Deng, and Y. Liu, "Mature fine tailings consolidation through microbial induced calcium carbonate precipitation," Canadian Journal of Civil Engineering, vol. 42, no. 11, pp. 975-978, 2015.

[3] E. Salifu, E. MacLachlan, K. R. Iyer, C. W. Knapp, and A. Tarantino, "Application of microbially induced calcite precipitation in erosion mitigation and stabilisation of sandy soil foreshore slopes: A preliminary investigation," Engineering Geology, vol. 201, pp. 96-105, 2016.

[4] H. Canakci, W. Sidik, and I. Halil Kilic, "Effect of bacterial calcium carbonate precipitation on compressibility and shear strength of organic soil," Soils and Foundations, vol. 55, no. 5, pp. 1211-1221, 2015.

[5] M. Umar, K. A. Kassim, and K. T. Ping Chiet, "Biological process of soil improvement in civil engineering: A review," Journal of Rock Mechanics and Geotechnical Engineering, vol. 8, no. 5, pp. 767-774, 2016.

[6] N. K. Dhami, A. Mukherjee, and M. S. Reddy, "Micrographical, minerological and nano-mechanical characterisation of microbial carbonates from urease and carbonic anhydrase producing bacteria," Ecological Engineering, vol. 94, pp. 443-454, 2016. 
[7] L. Cheng, M. A. Shahin, and D. Mujah, "Influence of key environmental conditions on microbially induced cementation for soil stabilization," Journal of Geotechnical and Geoenvironmental Engineering, vol. 143, no. 1, Article ID 04016083, 2017.

[8] M. B. Burbank, T. J. Weaver, B. C. Williams, and R. L. Crawford, "Urease activity of ureolytic bacteria isolated from six soils in which calcite was precipitated by indigenous bacteria," Geomicrobiology Journal, vol. 29, no. 4, pp. 389-395, 2012.

[9] V. Stabnikov, C. Jian, V. Ivanov, and Y. Li, "Halotolerant, alkaliphilic urease-producing bacteria from different climate zones and their application for biocementation of sand," World Journal of Microbiology and Biotechnology, vol. 29, no. 8, pp. 1453-1460, 2013.

[10] W. Li, L. Liu, W. Chen, L. Yu, W. Li, and H. Yu, "Calcium carbonate precipitation and crystal morphology induced by microbial carbonic anhydrase and other biological factors," Process Biochemistry, vol. 45, no. 6, pp. 1017-1021, 2010.

[11] K. Feng and B. M. Montoya, "Influence of Confinement and Cementation Level on the Behavior of Microbial-Induced Calcite Precipitated Sands under Monotonic Drained Loading," Journal of Geotechnical and Geoenvironmental Engineering, vol. 142, no. 1, Article ID 04015057, 2016.

[12] H. Lin, M. T. Suleiman, D. G. Brown, and E. Kavazanjian, "Mechanical behavior of sands treated by microbially induced carbonate precipitation," Journal of Geotechnical and Geoenvironmental Engineering, vol. 142, no. 2, Article ID 04015066, 2016.

[13] A. Gurbuz, Y. D. Sari, and Z. N. Yuksekdag, "Bacteria-Induced Cementation in Sandy Soils," Geomicrobiology Journal, vol. 32, no. 9, pp. 853-859, 2015.

[14] N. K. Dhami, M. S. Reddy, and A. Mukherjee, "Significant indicators for biomineralisation in sand of varying grain sizes," Construction and Building Materials, vol. 104, pp. 198-207, 2016.

[15] H. A. Abdel Gawwad, S. A. E.-A. Mohamed, and S. A. Mohammed, "Impact of magnesium chloride on the mechanical properties of innovative bio-mortar," Materials Letters, vol. 178, pp. 39-43, 2016.

[16] L. Cheng, C.-X. Qian, R.-X. Wang, and J.-Y. Wang, "Study on the mechanism of calcium carbonate formation induced by carbonate-mineralization microbe," Acta Chimica Sinica, vol. 65, no. 19, pp. 2133-2138, 2007.

[17] P. Anbu, C.-H. Kang, Y.-J. Shin, and J.-S. So, "Formations of calcium carbonate minerals by bacteria and its multiple applications," SpringerPlus, vol. 5, no. 1, article 250, pp. 1-26, 2016.

[18] B. S. Shashank, S. Sharma, S. Sowmya, R. A. Latha, P. S. Meenu, and D. N. Singh, "State-of-the-art on geotechnical engineering perspective on bio-mediated processes," Environmental Earth Sciences, vol. 75, no. 3, article 270, pp. 1-16, 2016.

[19] J. T. DeJong, M. B. Fritzges, and K. Nüsslein, "Microbially induced cementation to control sand response to undrained shear," Journal of Geotechnical and Geoenvironmental Engineering, vol. 132, no. 11, pp. 1381-1392, 2006.

[20] V. S. Whiffin, Microbial $\mathrm{CaCO}_{3}$ Precipitation for The Production of Biocement, Murdoch University, 2004.

[21] B. M. Mortensen, M. J. Haber, J. T. Dejong, L. F. Caslake, and D. C. Nelson, "Effects of environmental factors on microbial induced calcium carbonate precipitation," Journal of Applied Microbiology, vol. 111, no. 2, pp. 338-349, 2011.

[22] F. R. Jia, Y. M. Gao, Z. X. Peng et al., Biomineralization, Science Press, Beijing, China, 2009.
[23] E. R. Wang, W. J. Wang, H. Wang, R. Subhash, and C. Y. Su, "Describing asymmetric hysteretic F-V characteristics of a MR damper resulted form symmetric MR damper," Journal of Nanjing Normal University, vol. 8, no. 1, pp. 1-6, 2008.

[24] H. Yang, W. Yao, L. Yang et al., "The self-assembly of $\mathrm{CaCO} 3$ crystals in the presence of protein," Journal of Crystal Growth, vol. 311, no. 9, pp. 2682-2688, 2009.

[25] Y.-Q. Liu, G.-H. Lan, and P. Zeng, "Size-dependent calcium carbonate precipitation induced microbiologically in aerobic granules," Chemical Engineering Journal, vol. 285, pp. 341-348, 2016.

[26] Al-Thawadi S. and R. Cord-Ruwisch, "Calcium carbonate crystals formation by ureolytic bacteria isolated from Australian soil and sludge," Journal of Advanced Science and Engineering Research, vol. 2, no. 1, pp. 12-26, 2012.

[27] M. J. Lochhead, S. R. Letellier, and V. Vogel, "Assessing the role of interfacial electrostatics in oriented mineral nucleation at charged organic monolayers," Journal of Physical Chemistry B, vol. 101, no. 50, pp. 10821-10827, 1997.

[28] W. Zhong, H. Luo, and S. Hua, "Anionic coordination polyhedron growth units and crystal morphology," Journal of Synthetic Crystals, vol. 33, no. 4, pp. 475-478, 2004. 

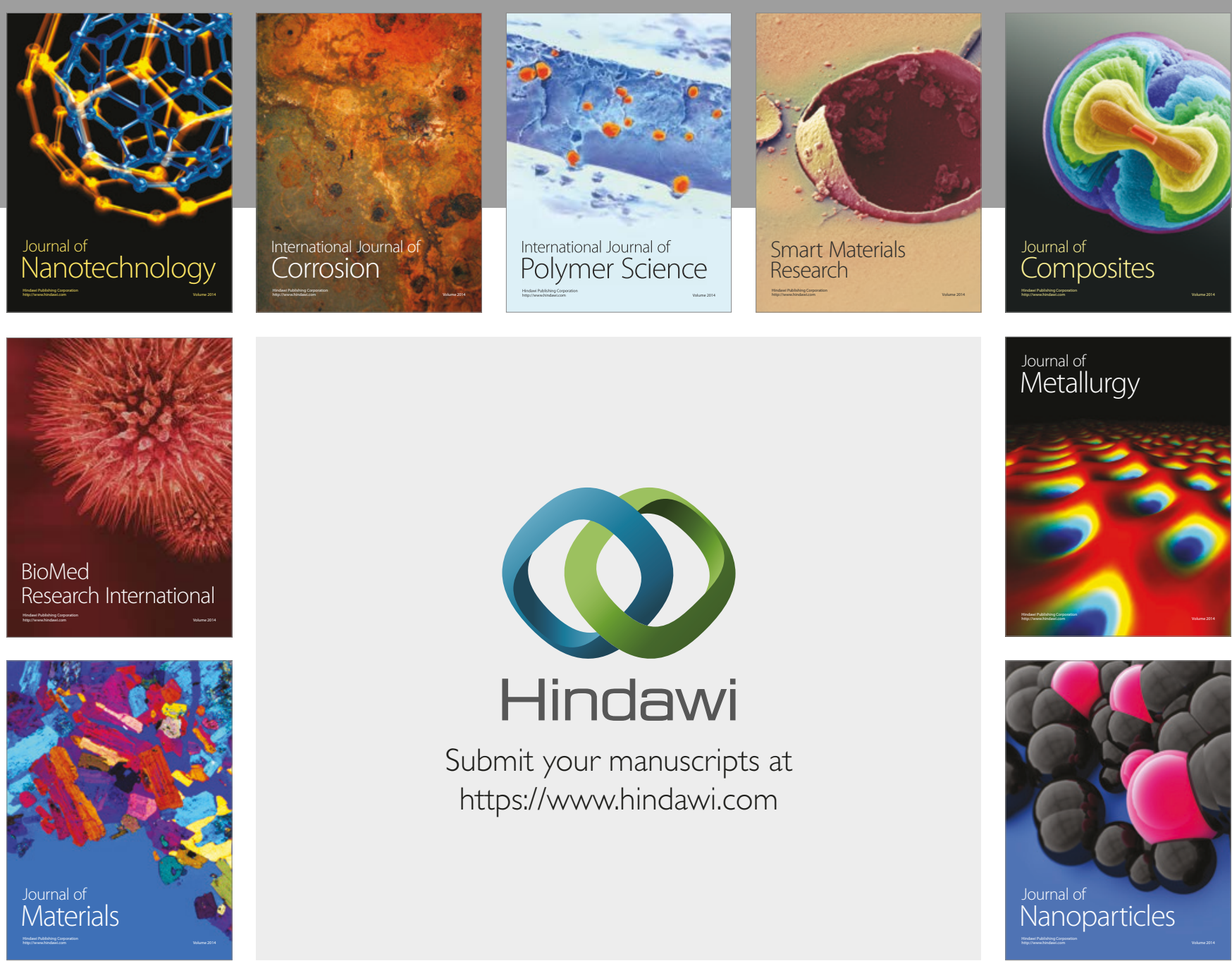

\section{Hindawi}

Submit your manuscripts at

https://www.hindawi.com
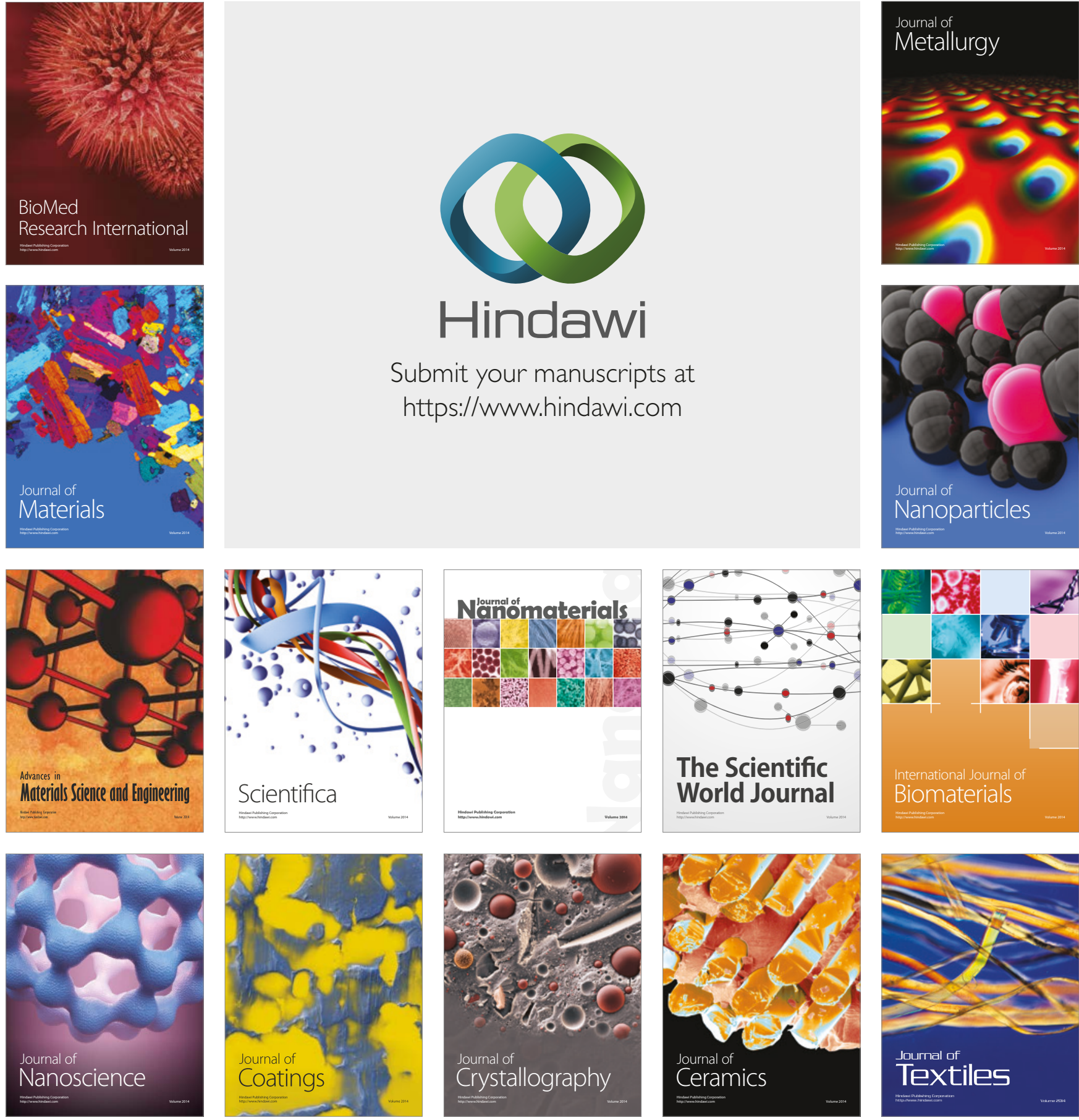

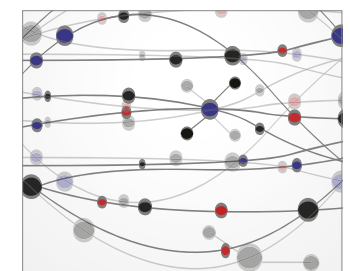

The Scientific World Journal
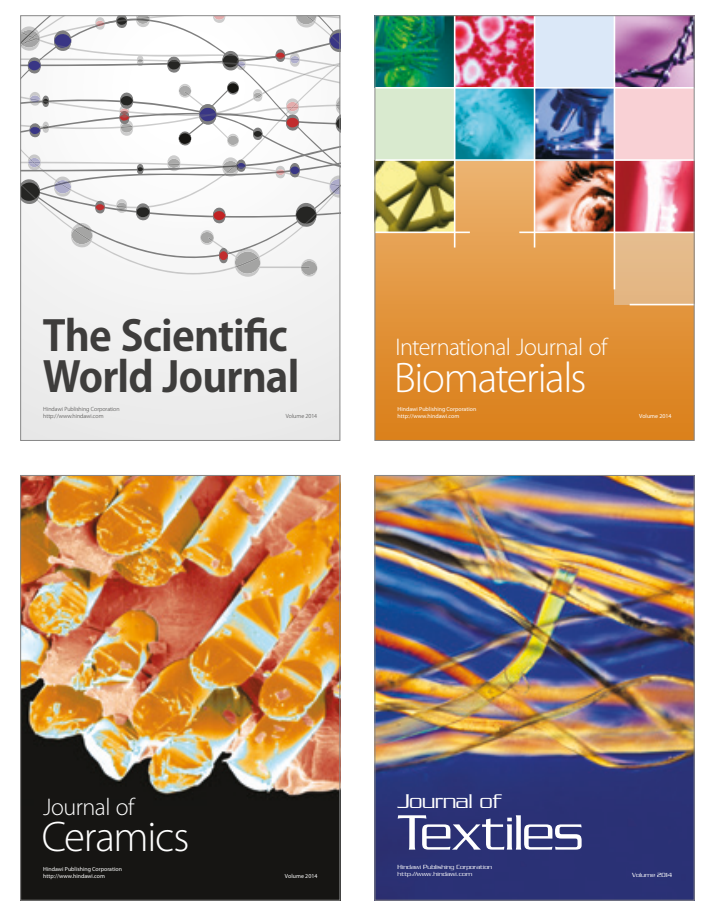